\title{
CliFEM - Climate Forcing and Erosion Modelling in the Sele River Basin (Southern Italy)
}

\author{
N. Diodato ${ }^{1}$, M. Fagnano $^{2}$, and I. Alberico ${ }^{3}$ \\ ${ }^{1}$ TEDASS - Technologies Interdepartmental Center for the Environmental Diagnostic and Sustainable Development, \\ University of Sannio, Via Bartolomeo Camerario 35, Benevento, Italy \\ ${ }^{2}$ DIAAT - Dipartimento Ingegneria Agraria e Agronomia del Territorio, University of Naples Federico II, \\ Via Università 100, Portici, Italy \\ ${ }^{3}$ CIRAM - Centro Interdipartimentale di Ricerca Ambiente, University of Naples Federico II, \\ Via Mezzocannone 16, Napoli, Italy
}

Received: 15 January 2009 - Revised: 23 July 2009 - Accepted: 25 Aug 2009 - Published: 14 October 2009

\begin{abstract}
This study presents a revised and scale-adapted Foster-Meyer-Onstad model (Foster et al., 1977) for the transport of soil erosion sediments under scarce input data, with the acronym CliFEM (Climate Forcing and Erosion Modelling). This new idea was addressed to develop a monthly time scale invariant Net Erosion model (NER), with the aim to consider the different erosion processes operating at different time scales in the Sele River Basin (South Italy), during 1973-2007 period. The sediment delivery ratio approach was applied to obtain an indirect estimate of the gross erosion too. The examined period was affected by a changeable weather regime, where extreme events may have contributed to exacerbate soil losses, although only the $19 \%$ of eroded sediment was delivered at outlet of the basin. The long-term average soil erosion was very high $\left(73 \mathrm{Mg} \mathrm{ha}^{-1}\right.$ per year $\left.\pm 58 \mathrm{Mg} \mathrm{ha}^{-1}\right)$. The estimate of monthly erosion showed catastrophic soil losses during the soil tillage season (August-October), with consequent land degradation of the hilly areas of the Sele River Basin.
\end{abstract}

\section{Introduction}

The full knowledge of climate drivers of soil erosion needs extended meteorological, hydrological and land-cover records and the knowledge of the processes linking weather and geomorphology at different time and spatial scales. The nature of such linkages remains still poorly understood for

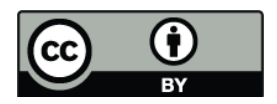

Correspondence to: I. Alberico (ialberic@unina.it) several Mediterranean Europe river basins (Rickson, 2006), where there aren't satisfactory geo-data series because of mutability, discontinuity and sparsity of the available data (Poesen and Hooke, 1997a). In these basins, stream and tillage erosion probably are the dominant sediment sources (Poesen and Hooke, 1997b) and are considered an important limiting factor of farm soil fertility (Lal, 2001). Prolonged or accelerated erosion events cause irreversible soil losses, thus reducing soil ecological functions such as biomass production and filtering capacity (Gobin et al., 2004). Changes in the climate time patterns may have important effects on the interaction among erosive rainfalls, vegetation covers and runoff, which can affect soil degradation. In Mediterranean areas, erosion is particularly pronounced both in the semiarid regions (200-300 $\mathrm{mm}_{\text {year }}{ }^{-1}$ ), and in the sub-humid ones (900-1500 $\mathrm{mm} \mathrm{year}^{-1}$ ) and the strong variability in annual precipitation with frequent events of extreme rainfalls may result in time-transgressive susceptibilities of regional erosion (after Boardman and Favis-Mortlock, 2001). Many studies were made on erosion simulations and on ecosystem responses to future climate changes (e.g., Newson and Lewin, 1991; Easterling et al., 2000; Yang et al., 2003; Nearing et al., 2005; Michael et al., 2005; Phillips et al., 2006; Quilbe et al., 2007), but few researches allowed to quantify the effects of past climate variability on the dynamics of geomorphological processes (Rumsby, 2001; Diodato, 2006; Foster et al., 2008), while they study episodic impacts of extreme rainfalls (e.g., Gomez et al., 1997; Hooke and Mant, 2000; Coppus and Imeson, 2002; Martínez-Casasnovas et al., 2002; Mul et al., 2008). Other researches are mainly based on plot covers and soil types and they cannot be scaled up to catchment scales (Dickinson and Collins, 2007).

Published by Copernicus Publications on behalf of the European Geosciences Union. 
Although various models are reported in literature, it is difficult to relate the occurrence of historical soil erosion rates to climate variability because there aren't long-term research projects in river basins, especially as regards the sediment data. Some authors (Larson et al., 1997; Boardman, 2006) stressed the need to study the driving variables of soil loss with an high frequency, for the importance of the extreme rain time-clusters on climate aggressiveness and thus on soil losses.

According to the aforementioned Authors, our effort was to produce monthly sediment budget, for develop a processbased time-scale invariant Net Erosion model (NER). Afterwards, monthly, seasonal and annual gross erosion rates were carried out within a down-scaling approach by using Sediment Delivery Ratio (SDR), on the contrary of up-scaling procedure commonly used by RUSLE (Renard et al., 1997). As remarked by Larson et al. (1997), the USLE-RUSLE approach is aimed to simulate the average long-term soil erosion, but it neglects land vulnerability during severe rainstorms because it was not designed to accurately simulate soil losses of single events.

CliFEM approach, derived from Foster et al. (1977), was developed to include the major conceptual advantages of some erosion models. However, while NER model was largely determined by the required experimental data, the SDR model was constrained by weakness of the available data in Sele River Basin. Another important characteristic of the NER model was to consider the different erosion processes at different time scales (from monthly to annual). The major weakness of the approach here proposed may be in the sediment data quality, and in the consequent uncertainty in Sediment Delivery Ratio, that is a critical point in many models (L. Borselli, personal communication, 2007).

\section{Model description}

The process-based monthly time scale invariant Net Erosion model (NER) was aimed to consider the erosion processes at different time scales. The amount of sediments from a basin (net erosion) is in fact generally much smaller than the amount indicated by soil loss rate (gross erosion). The ratio between net and gross erosion is the sediment delivery ratio (SDR). Considering then that only a fraction of the eroded soils is transported to the basin outlet, as indicated by SDR, we can use this link to evaluate the soil amount removed by water within the watershed slope. A well known relationship to convert net erosion to gross soil loss is the following:

$\mathrm{GER}=\frac{\mathrm{NER}}{\mathrm{SDR}}$

where GER is the monthly gross soil loss, NER is the net erosion, and SDR is the sediment delivery ratio.
Data exploration, development and model performance were supported by XLStatistics - Excel add-in Software for Statistical Data Analysis ${ }^{\circledR}$ Rodney Carr (1997-2007).

\subsection{Process-based monthly Net Erosion (NER) model}

In this study we expanded and adapted a sub-routine introduced by Foster et al. (1977) to take into account the runoff shear stress effect on soil detachment for single storms. The new Time Scale-Invariant process-based monthly Net ERosion (NER $\mathrm{NSI}_{\text {) }}$ model was used for predicting monthly net erosion over medium basins (around $3000 \mathrm{~km}^{2}$ ). The hydrological ecosystem module, considers the interrelationships of rainfall erosivity, runoff, erodibility and vegetation cover as follows:

$$
\begin{aligned}
\mathrm{NER}_{\mathrm{TSI}}= & K \cdot\left(\alpha \cdot \overline{E I}_{m}+\beta \cdot \bar{Q}_{m}\right)^{\psi} \cdot \\
& \exp \left(-\gamma \cdot\left(\overline{\mathrm{NDVI}}_{m} \cdot 100\right)\right)
\end{aligned}
$$

where the first term in bracket is the modified erosivity factor as adapted by Foster et al. (1977), while the second term is the modified vegetation erosion exponential function, as adapted by Thornes (1990); $K$ is the RUSLE erodibility factor $\left(\mathrm{Mg} \mathrm{h} \mathrm{MJ}^{-1} \mathrm{~mm}^{-1}\right)$ changing with basin soils, that was set equal to 0.0362 (an approximate range of $K$ values can be founded in van der Knijff et al., 2000); $\alpha, \beta$ and $\psi$ are empirical parameters equal to $0.40,0.60$ and 2.05 , respectively; $\gamma$ is the parameter of the vegetation exponential function, set equal to 0.04 (early placed equal to 0.07 by Thornes, 1990). Note that the terms are averaged values upon an area (in our case of the basin-area).

Monthly rainfall erosivity at gauged station $E I_{m}$ (MJ mm ha ${ }^{-1} \mathrm{~h}^{-1}$ month $^{-1}$ ) was derived from rainfall measurements in the Italian area, according to RUSLE scheme (Diodato, 2005a):

$E I_{m}=0.1174 \cdot\left(\sqrt{p} \cdot d^{0.53} \cdot h^{1.18}\right)$

where $p$ is the monthly precipitation amount $(\mathrm{mm}), d$ is the monthly maximum daily rainfall $(\mathrm{mm})$, and $h$ is the monthly maximum hourly rainfall $(\mathrm{mm})$, respectively. In this approach, $d$ and $h$ are descriptors of the extreme rainfalls (storms and heavy showers respectively) (Diodato, 2005a). Since long series of meteorological variables do not include hourly rainfall intensities (i.e. the term $h$ ), the Eq. (3) was simplified as in the Eq. (4) (Diodato and Bellocchi, 2009a):

$E I_{m}=0.0400 \cdot\left(p^{0.35} \cdot d^{0.60} \cdot\left(d \cdot \alpha_{m}\right)^{0.70}\right)$

where $\alpha_{m}$ is a seasonal scale-factor in function of the month, $m=1, \ldots, 12$ :

$\alpha_{m}=\left[1-0.30 \cdot \cos \left(2 \pi\left(\frac{m}{26-m}\right)\right)\right]^{3}$

Since with Eq. (3) it was not possible to have continuity in erosivity modelling between the first and the last time of the 
series, the whole erosivity dataset was subjected to a rigorous control of internal consistency (e.g., inspection and crosscheck of the extremes of rain and hourly rain of the closest stations, zero of the erosivity values with temperature close to zero degrees during cold rains, check of outlier values).

The erosivity value averaged over the basin was calculated according to the following multiple linear regression $\left(r^{2}=0.93\right)$ :

$\overline{E I}_{m}=0.684 \cdot E I_{m(P)}+0.722 \cdot E I_{m(B)}$

where $E I_{m(P)}$ and $E I_{m(B)}$ are the estimated rainfall erosivity with Eq. (4) at Pontecagnano and Buccino stations, respectively.

In lack of experimental measurements (after 1994 year in this specific case), monthly runoff $\left(\bar{Q}_{m}\right)$ was estimated by adapting the Vandewiele et al. (1992) approach:

$\bar{Q}_{m}=\eta_{m} \cdot\left[\bar{p}_{m}-\overline{\operatorname{AET}}_{m}\left(0.5-\exp \left(-\frac{\bar{p}_{m}}{\overline{\mathrm{AET}}_{m}}\right)\right)\right]$

where $\bar{p}_{m}$ and $\overline{\mathrm{AET}}_{m}$ are the average values of rainfalls and actual evapotranspiration, respectively; $\eta_{m}$ are the monthly experimental coefficients related to soil (see Table 1, first row). The performance of calibration made with 46 monthly data was significant $\left(r^{2}=0.90\right)$.

$\bar{p}_{m}$ was estimated according to the following multiple nonlinear regression $\left(r^{2}=0.94\right)$ :

$\bar{p}_{m}=\left(p_{m(P)}\right)^{0.70}+0.90 \cdot p_{m(B)}$

where $p_{m(P)}$ and $p_{m(B)}$ are the measured monthly rainfalls at Pontecagnano and Buccino stations, respectively.

Monthly AET was derived from Global Rapid Integrated Monitoring System (Global-RIMS available at webpage http: //rbis.sr.unh.edu/). For the last years (2001-2007), where AET was not updated in RIMS-database, the following empirical sub-model was approached to transfer AET from point-site to averaged AET over the SRB compatible with RIMS output:

$\overline{\mathrm{AET}}_{m}=0.570 \cdot \mathrm{AET}_{m(P)} \cdot\left(0.4+v_{m}\right)^{3}+7.60$

where $\operatorname{AET}_{m(P)}$ is the actual evapotranspiration at Pontecagnano site in mm month ${ }^{-1}$ (derived from RAN-UCEA Network, www.ucea.it/), and $v_{m}$ are the monthly experimental coefficients related to the soil moisture, (see Table 1, second row). Also in this case, the calibration process, made with 24 RIMS monthly AET data, gave a significant correlation $\left(r^{2}=0.90\right)$.

NDVI-biomass seasonal regime was represented by monthly MODIS (MOderate resolution Imaging Spectroradiometer) composites, averaged on the 2000-2007 period, downloaded from Northern Eurasia Earth Science Partnership Initiative Monthly Products, NASA web site (http: //disc.sci.gsfc.nasa.gov/techlab/giovanni/\#maincontent/). In this first approach the NDVI seasonal regime over SRB was set constant for the whole simulation period, since MODIS NDVI data were not available before 2000 year. However, for accounting tillage erosion in Eq. (2) when running it for erosion reconstruction, the NDVI values were adjusted in autumn season multiplying it for the coefficients reported in Table 1 (third row).

\subsection{Gross erosion evaluation}

The simulation of daily SDR made with the Soil and Water Assessment Tool - SWAT (Arnold and Williams, 1995) was conceptually revised and adapted to the monthly scale by the following equation:

$\mathrm{SDR}_{m}=\left(a+b \frac{\bar{Q}_{m}}{\overline{E I}_{m}}\right)^{c}$

where the terms of the ratio are those described above; $a, b$ and $c$ are three coefficients equal to $0.035,0.010$ and 0.50 respectively, derived imposing a values of SDR-long-term equal to 0.19 , which, in turn, was supported by human-expert (L. Borselli, personal communication, 2007), and checked by CSIRO abaco (Lu et al., 2003) on the basis of the basin area and the storm duration.

\subsection{Estimation of tolerable soil loss}

Since the effects of soil erosion on soil productivity depend on the depth of these soils, it is possible to define the tolerable amount of soil loss when the soil depth of an area is known. Combining the information gathered on topsoil loss depth $(S d)$ and proportion of land degraded (PLD), the tolerable soil loss (TSL) may be calculated by using the Bhattacharyya et al. (2007) approach:

$\mathrm{TSL}=\frac{\mathrm{PLD} \cdot D \cdot S p}{T}$

where PLD is the proportion of land downgraded to at least the next depth class (\%, assumed equal to $15 \%), T$ is the time (years, assumed equal to 100 ), $D$ is the bulk density of the soil (assumed equal to $1.4 \mathrm{Mg} \mathrm{m}^{-3}$ ), $S d$ is the soil depth (assumed equal to $130 \mathrm{~cm}$ ).

\section{Results and discussions}

\subsection{Study site}

The Sele River Basin (SRB) is located across the Southern Campania and Western Basilicata regions (Fig. 1). The basin can be divided in two main zones: the dolomitic limestone zone, in the mountainous and hilly areas, and the marinealluvial zone, in the plainy areas. The 130-km length Sele river starts in the Cervati Mountains (1855 m a.s.l.), its basin covers an area of about $3000 \mathrm{~km}^{2}$ extending to adjacent Sele plain characterized by different land uses, such as crops, 
Table 1. Monthly empirical coefficients $\eta_{m}$ and $v_{m}$ arranging soil moisture for the Eqs. (5) and (6), respectively, and $\tau_{c}$ arranging tillage erosion in NDVI autumnal values.

\begin{tabular}{ccccccccccccc}
\hline & $\mathrm{J}$ & $\mathrm{F}$ & $\mathrm{M}$ & $\mathrm{A}$ & $\mathrm{M}$ & $\mathrm{J}$ & $\mathrm{J}$ & $\mathrm{A}$ & $\mathrm{S}$ & $\mathrm{O}$ & $\mathrm{N}$ & $\mathrm{D}$ \\
\hline$\eta_{m}$ & 0.80 & 0.80 & 0.60 & 0.60 & 0.40 & 0.10 & 0.10 & 0.10 & 0.06 & 0.20 & 0.40 & 0.80 \\
$v_{m}$ & 0.30 & 0.30 & 0.30 & 0.85 & 0.80 & 0.80 & 0.80 & 0.50 & 0.60 & 0.64 & 0.70 & 0.40 \\
$\tau_{c}$ & 1.00 & 1.00 & 1.00 & 1.00 & 1.00 & 1.00 & 1.00 & 0.94 & 0.77 & 0.82 & 0.89 & 0.95 \\
\hline
\end{tabular}
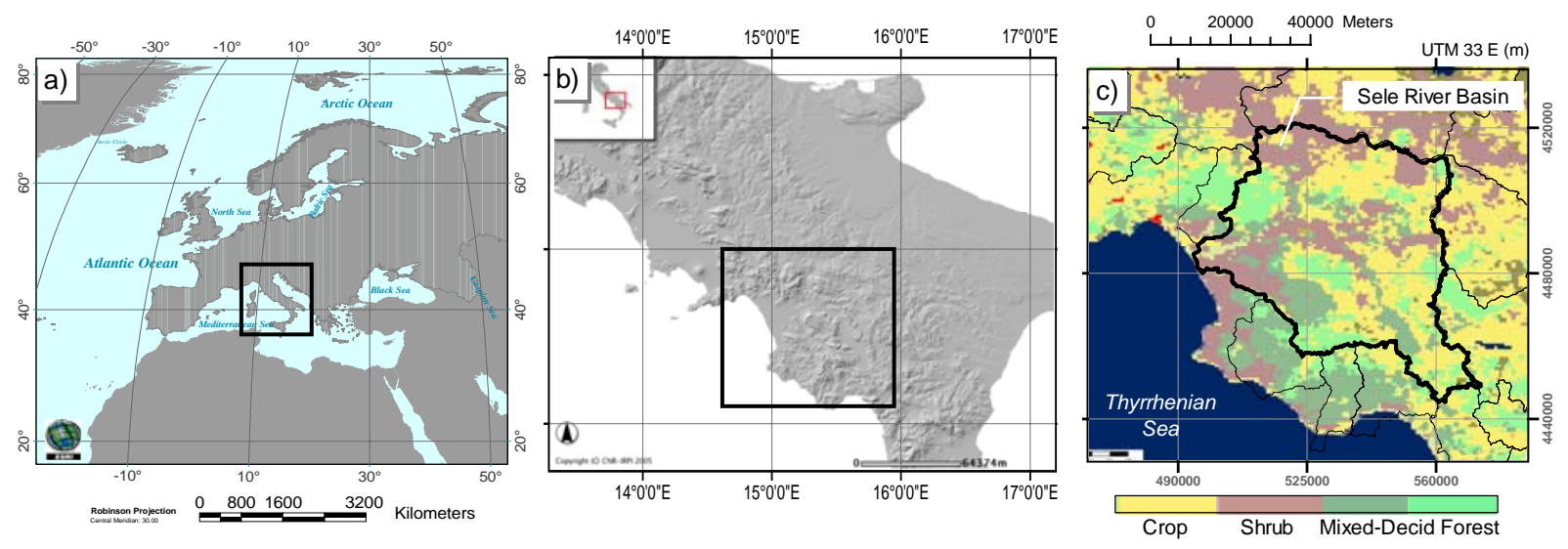

Fig. 1. Geographical setting (a) and peninsular Southern Italy (b), with land-cover across Sele River Basin in bold line (c). Land-cover source: http://hydis.eng.uci.edu/gwadi/.

shrub and mixed-deciduous woods (Fig. 1c). The Sele Plain comes from the aggradation of a Plio-Quaternary depression located along the rifted inner margin of the southern Apennine Mountains. It is about $400 \mathrm{~km}^{2}$ wide and has a triangular shape, defined seawards by a straight sand coast stretching between the towns of Salerno and Agropoli and closed landwards from Lattari and Picentini Mts. to N-NW and from Alburni, Soprano-Sottano and Cilento Mts. to SE. The climate of the SRB is of Mediterranean type, but with spatio-temporal differences in both precipitation and temperature. The average (1957-2000) annual precipitation, estimated over 62 raingauges, ranges from 700 to $2000 \mathrm{~mm}$, with mean and standard deviation of $1180 \pm 367 \mathrm{~mm}$, respectively. The original forest-covers have been fragmented by agriculture that is the main activity in this region. Especially during and after the typical tillage period (September-December), erosive rainfalls are very hazardous in this area that is affected by a mixed regime of frontal rainstorms and localised deluges (Fig. 2a). Annual rain-erosivity ranges from 600 to $4000 \mathrm{MJ} \mathrm{mm} \mathrm{ha}^{-1} \mathrm{~h}^{-1}$ in this part of Southern Italy (Diodato and Fagnano, 2009), with areal mean and standard deviation of $2000 \pm 883 \mathrm{MJ} \mathrm{mm} \mathrm{ha}^{-1} \mathrm{~h}^{-1}$ (Fig. 2b).

In this context, weather has an important impact on erosion and on agricultural activity that plays an essential role in the economy and landscape of SRB.

The dataset supporting the present work consisted of two databases: one for model calibration and another for erosion reconstruction. The first database included hydrological and sediment transport data for Calore River Basin (Diodato, 2006), a region adjacent to the SRB and with geographical features and extension very similar to SRB. The second one consisted of a long-term hydrological database for SRB, including precipitation, discharge and evapotranspiration data. The pluviometrical database included daily records from 50 raingauges over SRB (SIMN 1950-2000). Although longterm homogeneous pluviometrical series were available for only two stations (Pontecagnano and Buccino), their consistence allowed us to well represent the space and time variability of data in the whole SRB basin. The runoff value records were registered at Albanella gauge, close to SRB outlet.

\subsection{Exploratory data analysis}

Exploratory data analysis was part of the preliminary results, which should always be done before of more formal analysis and discussions. It was obvious that both net and gross erosion would have a very similar seasonal regime (histograms in Fig. 3a and b, respectively). Confidence interval at $95 \%$ were drawn too (vertical lines passing the single bars in Fig. 3a, b). Erosion regime was clearly autumnal with values positioned around a mean rate of $8 \mathrm{Mg} \mathrm{ha}^{-1}$ per month.

The frequency distribution was strongly skewed and bimodal for net erosion (Fig. 5a 1 ), as well as for gross erosion (figure not shown). If annual gross erosion amounts were ordered from the highest to the lowest value over the 35-year 

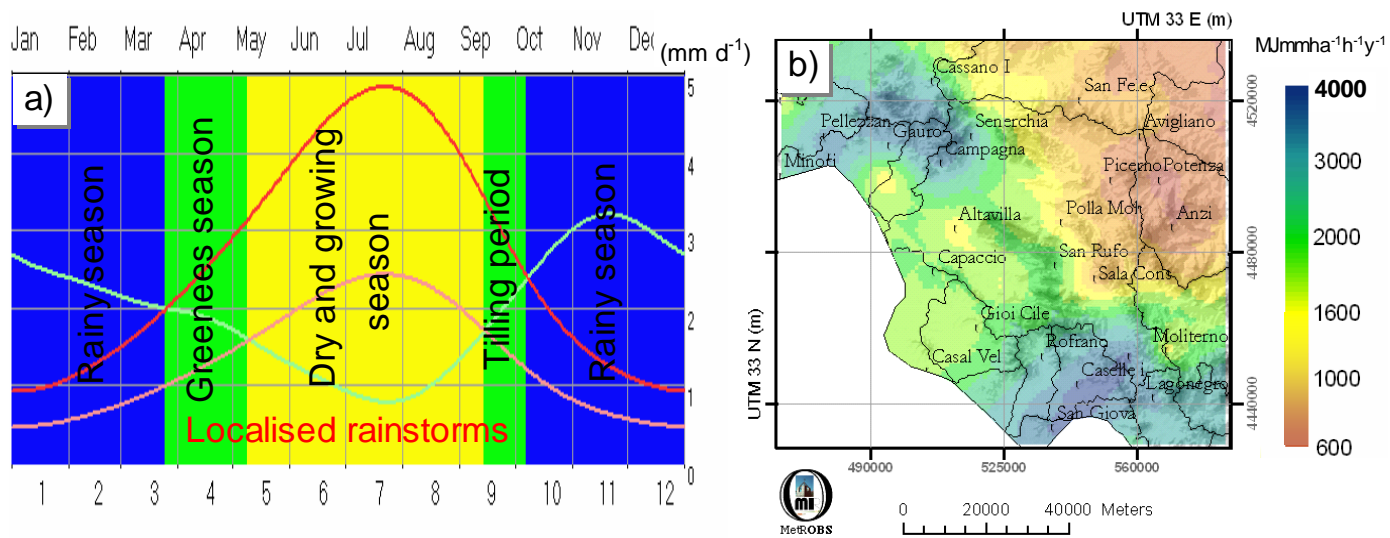

Fig. 2. (a): bioclimogram of Sele River Basin (SRB) with seasonal regime (coloured bands), and monthly trend of precipitation (turquoise curve), reference evapotranspiration (red curve) with 0.5 ETo (violet curve), as arranged by New LocClim - FAO software (http://www.fao. org/sd/dim_en3/en3_051002_en.htm); (b): kriged map of long-term average annual rainfall erosivity over and around SRB by Diodato and Fagnano (2009).

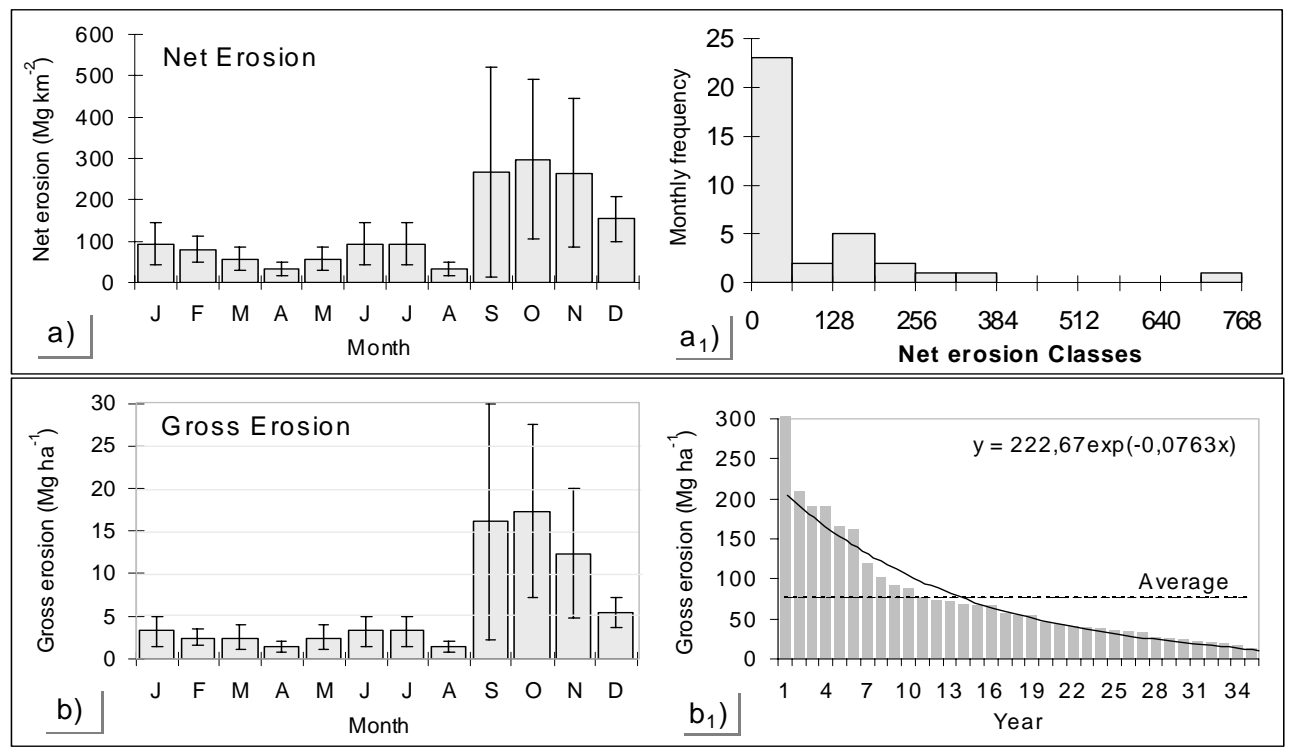

Fig. 3. Long-term monthly predicted average for net erosion (a), and gross erosion (b) with related confidence interval at $95 \%$ (vertical lines passing on bars); net erosion frequency distribution $\left(\mathbf{a}_{1}\right)$, and ordered gross erosion amount (histogram in $\mathbf{b}_{1}$ ) for the 35 -years period (1973-2007) with overimposed the related average value (horizontal dotted line) and exponential model (curve) at Sele River Basin.

period, the resulting curve was an exponential equation: $y=a \cdot \exp (b \cdot t)$, where $y=$ soil loss, $t=$ year number, and $a$ and $b=$ two constants (Fig. $3 b_{1}$ ).

Figure 3 shows that in only 10 of the 35 years the soil losses exceeded the long-term average (horizontal dotted line), with soil erosion accounting for $60 \%$ of the total estimated soil eroded. These examples illustrate the dominance of relatively few events in the determination of long-term erosion average.

Although erosion is a natural process and thus is naturally variable with climate, soils and topography, the anthropic in- fluence can make the landscape more or less resilient to climate events (Morgan, 2005). Increased erosion of soil by water was, in fact, a problem since man began to cultivate the land. In some Mediterranean areas, such as in the SRB, erosion is probably increased with deforestation since the Medieval age.

Hydrological mega-events, occurred with possible and major flood disasters, were annotated only from the XVIII century, some of which were of high impact in terms of human suffering, losses in property, and extensive disruption of business activities (Esposito et al., 2003). 


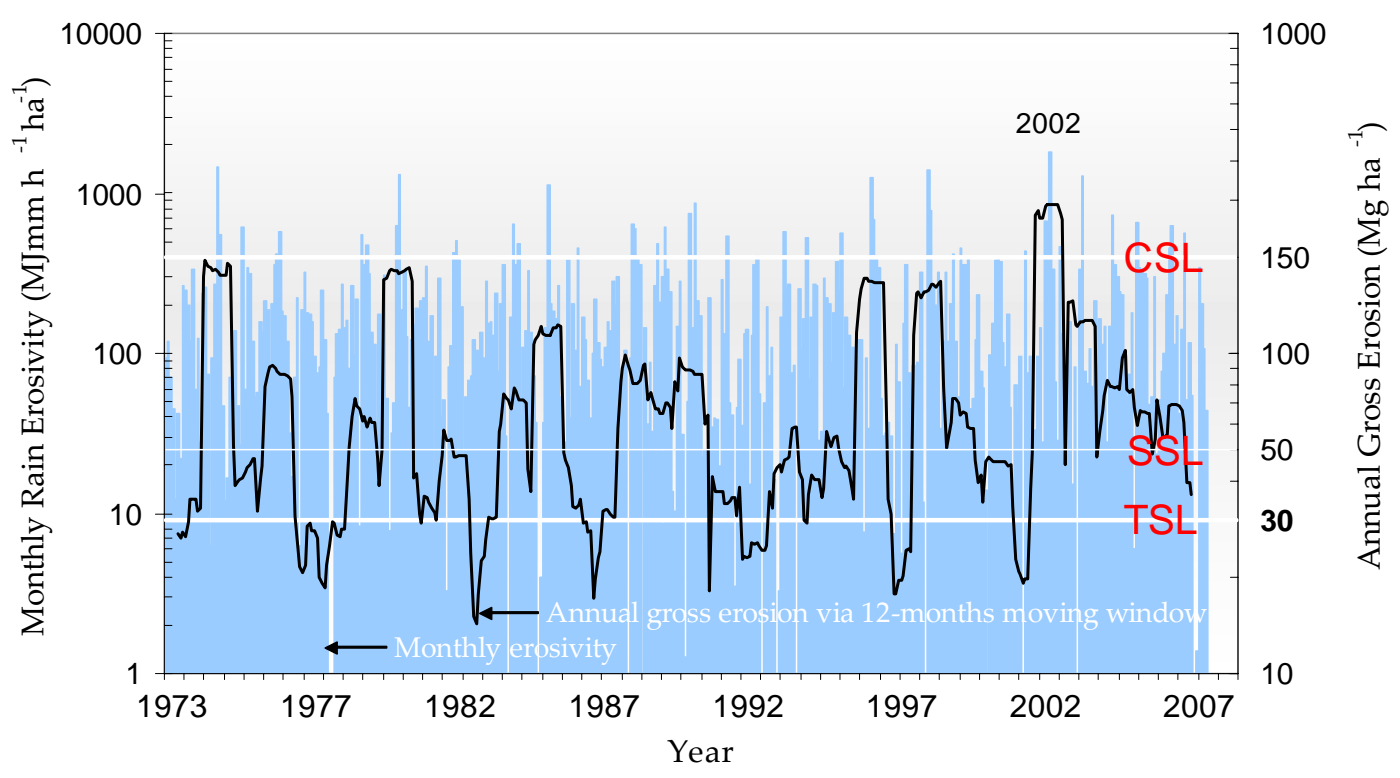

Fig. 4. Monthly variability of simulated gross erosion for the period 1973-2007 (blue histogram) over Sele River Basin, with overimposed cumulate erosion annual moving window (black line); Tolerable Soil Loss (TSL), Severe Soil Loss (SSL) and Catastrophic Soil Loss (CSL) threshold values are signed by horizontal white lines, according to Zachar (1982) guidelines.

\subsection{Spatially integrated effects in long-time erosion series}

\subsubsection{Gross erosion timing}

The net erosion can be reasonably converted to the gross soil losses (Fig. 4). The long-term average soil erosion was very high $\left(73 \mathrm{Mg} \mathrm{ha}^{-1}\right.$ per year $\left.\pm 58 \mathrm{Mg} \mathrm{ha}^{-1}\right)$. Progressive yearly averaged values during 1973-2007 period (bold black line in Fig. 4) showed a changeable trend with short intervals carachterized by negligible soil losses, followed by periods with erosion above the Tolerable Soil Loss (TLS), and often above severe erosion rates too (SSL line). At the beginning of the 1990 decade, it was evident a more irregular temporalpattern, with the highest annual erosion $\left(264 \mathrm{Mgha}^{-1}\right.$ in 2002). This was also confirmed by an increase in erosion 75 th quantile $\left(+25 \mathrm{Mg} \mathrm{ha}^{-1}\right)$ upon the last decade, as compared to the previous one.

Weather and climate shifts strongly affected erosion seasonal and interannual regime, showing large fluctuations from month-to-month (Fig. 5). This was in agreement with the large instability of the agrosystems of the basin, that deserves attention and immediate alert, especially, for the continuous exceeding of TSL values and for the periodical exceeding of the catastrophic threshold (CSL) too, especially during the last decade. The recent decade in fact showed the alternation of quiet-and-longer dry intervals with storminess periods when soil was more vulnerable to tillage and post-tillage erosion periods (between the end August to December). Hydrological shifts are known to occur because climate changes and meteorological and environmental controls affect probability, timing, and magnitude of specific basinresponse-producing mechanisms (after Bartlein and Prentice, 1989; Katz and Brown, 1992). These events may be grouped in some years or months according to storms climatic variability over interannual to century scales (after Garcia-Oliva et al., 1995; D'Odorico et al., 2001; Hollinger et al., 2002; Peterson et al., 2002).

\subsubsection{Seasonal investigation}

Seasonal changes in the soil erosion climatologies occurred in both gross and net erosion, especially in autumn and early of the winter season, as it is evident from the couples of bars shown in Fig. 5 (a, b), that compare the last period (19952007), to the first one (1973-1994). A reduction in soil erosion occurred during last decades in March (-12), April $(-9 \%)$, May $(-8 \%)$, and mainly in November $(-41 \%)$. On the contrary, there was an increase on July $(+78 \%)$, August $(+72 \%)$, December $(+39 \%)$, January $(+41 \%)$ and, especially, in September $(+106 \%)$, increasing the soil loss mean rate from $6 \mathrm{Mg} \mathrm{ha}^{-1}$ to $33 \mathrm{Mgha}^{-1}$ (see Fig. 7a, b). However, only the $19 \%$ of eroded soil was lost, implying that about $81 \%$ of it was delivered to the valley system. Negligible changes occurred in the other months for both the erosion types.

In this changeable weather regime, September was characterized by very stormy periods, in different areas of Mediterranean lands (Diodato and Bellocchi, 2009b), thus indicating a shift towards autumn of some conditions of summer Mediterranean climate (Millán et al., 2005). 

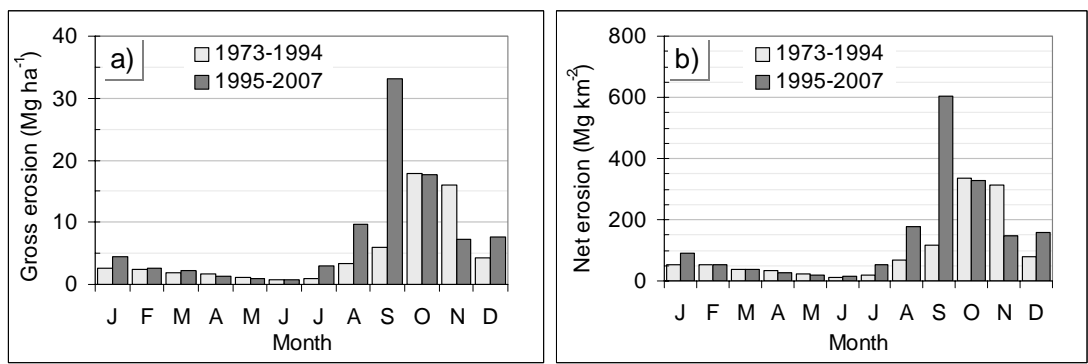

Fig. 5. Comparison of the monthly average for predicted gross erosion (a), and net erosion (b) between the 1973-1994 and 1995-2007 periods.

\subsection{Model performance}

The simulation of soil detachment and transport was coupled with the surface runoff modelling, following a reconciling approach from Foster et al. (1977) and Thornes (1990). Gully erosion processes were not explicitly simulated in our model and the vegetation cover was considered variable among the months but constant over the years. The coefficients of Eqs. (2), (4), (5), (6) and (7) were optimized by a calibration process against the respective monthly values by using a solver to minimize the square error of estimation.

For net erosion calibration model of the Eq. (2), the solver system for Calore River Basin was run also at different timeaggregation scales, monthly plus seasonal (Fig. 6a, b), and annual (figure not shown). Determination coefficients were very high ( $r^{2}$ from 0.94 to 0.98$)$. On monthly and seasonal aggregation scales, the respective erosion box-and-Whisker plots (in $\mathrm{a}_{1}$ and $\mathrm{b}_{1}$ ) showed that the actual distribution was similar to the simulated one.

For monthly rainfall erosivity, runoff, and precipitation of Eqs. (6), (7) and (8), respectively, the solver system was run to obtain averaged variables over Sele River Basin with very good approximation (Fig. 7). Efficiency measures, derived from Nash and Sutcliffe (1970) algorithm, were also in agreement with the very low mean square error to the observed variance, with values equal to $0.93,0.90$ and 0.94 , respectively for the three variables.

\section{Conclusions}

The most used models in soil erosion simulation don't include all the important soil erosion processes occurring in Mediterranean environments such as gully and stream erosion (Poesen and Hooke, 1997). This is especially true because usually there are few available data about landcover and land-use variations, hydrological features, sediment delivery ratio, channel erosion processes. Also the new model proposed in this work suffers of this weakness. The reconstructed series of erosion values for Sele River Basin are considered a sufficiently homogeneous sequence, but the limit of our approach is the uncertainty in estimat- ing the amount of exported sediment, which was involved in NER-model calibration. Temporal trends can be considered, however, a good indicator of the scenario. On the other hand, the average quantity of gross eroded soil here obtained ( $73 \mathrm{Mg} \mathrm{ha}^{-1}$ per year) was similar to that predicted by an adapted PISA model in SRB $\left(90 \mathrm{Mg} \mathrm{ha}^{-1}\right.$ per year) (Bazzoffi and Van Rompaey, 2003) and to that predicted by RUSLE approach in the Tusciano river basin $\left(57 \mathrm{Mg} \mathrm{ha}^{-1}\right.$ per year), a sub-basin of the SRB (Ducci et al., 2007). Furthermore, field experiments showed soil losses of $100 \mathrm{Mg} \mathrm{ha}^{-1}$ in one year of erosion (1981) in Piedmont vineyards (Tropeano, 1983), $130 \mathrm{Mg} \mathrm{ha}^{-1}$ per event with frequency of about 6-year period in the central Italy (Bazzoffi et al., 1997), and up to $54-88 \mathrm{Mg} \mathrm{ha}^{-1}$ per year in southeast Spain (Poesen et al., 1997b). Also in more recent experiments, the mean annual erosion rates were included in the range 65$116 \mathrm{Mg} \mathrm{ha}^{-1}$ per year, in the Comunelli catchment reservoir (Sicily island) (Onori et al., 2006) and in Yatagan (Western Turkey) basin that is characterized by intensive agricultural activities (Saç et al., 2007). Also long-term SDR value, used to convert net to gross erosion, was coherent with those referred in the European Communities Report on Soil Erosion Risk Assessment in Italy (Van Rompaey et al., 2003).

Therefore, a mean rate included in a 95th confidence interval of $53-93 \mathrm{Mg} \mathrm{ha}^{-1}$ per year predicted by CliFEM approach was considered a good estimation.

Considering that the months following soil tillage (from August to November) are the most hazardous for soil erosion in SRB, all the agro-environmental measures aimed to reduce soil erodibility and to increase soil cover, such as conservative soil tillage and perennial cover crops in orchards and vineyards, have to be strengthened and spread. The effectiveness of conservative cropping systems was also confirmed by field experiments made nearby $\mathrm{SRB}$, in which soil cover with wheat crop residues allowed an almost complete reduction of erosion in comparison with tilled soil $\left(2.291 \mathrm{Mgha}^{-1} \mathrm{y}^{-1}\right)$, showing soil losses $\left(0.015 \mathrm{Mg} \mathrm{ha}^{-1} \mathrm{y}^{-1}\right)$ not different from the permanent meadow $\left(0.004 \mathrm{Mg} \mathrm{ha}^{-1} \mathrm{y}^{-1}\right)$ as a consequence of an intense rain event (Maximum Intensity $=32.4 \mathrm{~mm} \mathrm{~h}^{-1}$ ) recorded on 2 August (Fagnano et al., 2000). 


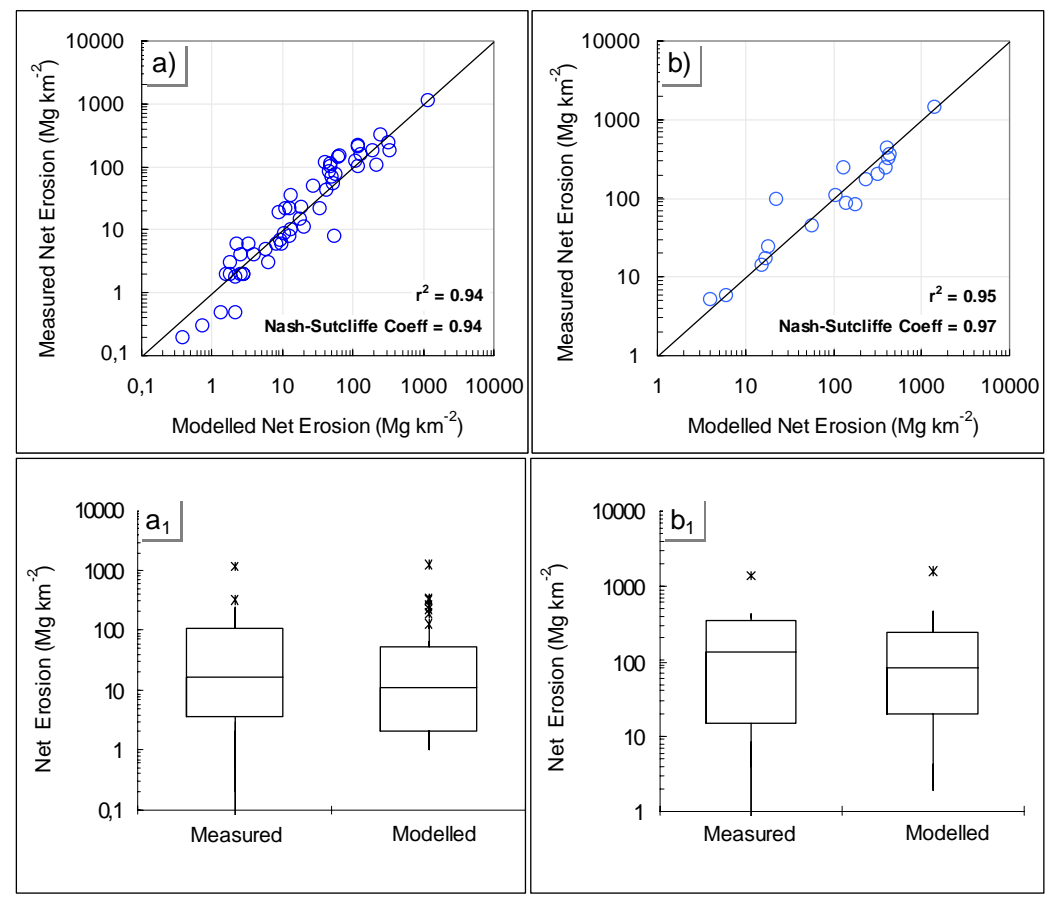

Fig. 6. Scatterplots between modelled and measured net erosion upon Calore River Basin (calibration dataset 1957-1961), at timeaggregation for monthly (a) and seasonal (b), with respective box-and-Whisker plots $\left(\mathbf{a}_{1}\right.$ and $\left.\mathbf{b}_{1}\right)$.
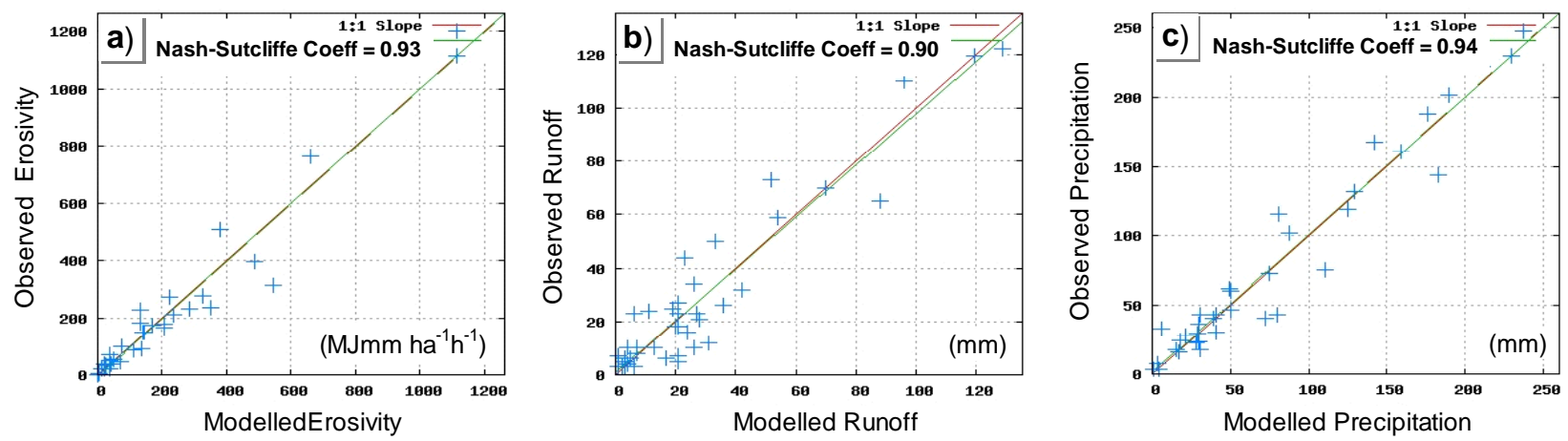

Fig. 7. Scatterplots between modelled and observed monthly precipitation (a), monthly rainfall erosivity (b), and monthly surface runoff (c), with efficiency-measured Nash-Sutcliffe, over Sele River Basin (Arranged by Web GIS-based Hydrograph Analysis Tool, Lim et al., 2005).

The information about the periods of soil losses, obtained in the above mentioned studies, could help farmers and policy makers to aim toward a sustainable cropland management, particularly in hilly areas such as SRB, where mean annual soil loss is expected to be up to $70 \mathrm{Mg} \mathrm{ha}^{-1}$ per year.

The environmental and social costs of these levels of erosion are very high, as reported by Torri et al. (2006) in their review of soil erosion in Italy. Further environmental effects of soil erosion are the worsening of topsoil fertility and agricultural productivity and the increase of sediment and contaminants transport from agricultural fields to the surface waters (Toy et al., 2002).
Acknowledgements. The authors wish to acknowledge two anonymous reviewers whose suggestions greatly improve the manuscript. This study was financially supported by VECTOR Project (line 2 VULCOST- chief, Bruno D'Argenio).

Edited by: L. Ferraris

Reviewed by: two anonymous referees

\section{References}

Arnold, J. G. and Williams, J. R.: A continuous time water and sediment routing model for large basins, J. Hydraul. Div. - ASCE, 121, 171-183, 1995. 
Bartlein, P. J. and Prentice, I C.: Orbital variations, climate and paleoecology, Trends Ecol. Evol., 4, 195-199, 1989.

Bhattacharyya, T., Babu, R., Sarkar, D., Mandal, C., Dhyani, B. L., and Nagar, A. P.: Soil loss and crop productivity model in humid subtropical India, Curr. Sci. India, 93, 1397-1403, 2007.

Bazzoffi, P., Pellegrini, S., Chisci, G., Papini, R., and Scagnozzi, A.: Erosion and discharge at catchment and field scales in argillous soils ad different use in Era Valley, Agricoltura Ricerca, 170, 520, 1997 (in Italian).

Bazzoffi, P. and Van Rompaey, A.: PISA model to assess offfarm sediment flow indicator at watershed scale in Italy. In Proc. OECD: Agricultural impacts on soil erosion and soil biodiversity: developing indicators for policy analysis, Rome, 263-272, 25-28 March 2003.

Boardman, J. D. and Favis-Mortlock, T.: How will future climate change and land-use change affect rates of erosion on agricultural land, in: Soil Erosion Research for the 21st Century, Am. Soc. Agric. Biol. Eng., Honolulu, Hawaii, 498-501, 3-5 January 2001.

Boardman, J.: Soil erosion science: Reflections on the limitations of current approaches, Catena, 68, 73-86, 2006.

Coppus, R. and Imeson, A. C.: Extreme events controlling erosion and sediment transport in a semi-arid sub-Andean Valley, Earth Surf. Proc. Land., 27, 1365-1375, 2002.

Dickinson, A. and Collins, R.: Predicting erosion and sediment yield at catchment scale, in: Soil Erosion Multiple Scales, edited by: Penning de Vries, F. W. T., Agus, F., and Kerr, J., CABI Publishing, 317-342, 2007.

Diodato, N.: Predicting RUSLE (Revised Universal Soil Loss Equation) monthly erosivity index from readily available rainfall data in Mediterranean area, The Environmentalist, 26, 63-70, 2005.

Diodato, N.: Modelling net erosion responses to enviroclimatic changes recorded upon multisecular timescales, Geomorphology, 80, 164-177, 2006.

Diodato, N. and Bellocchi, G.: Assessing and modelling changes in rainfall erosivity at different climate scales, Earth Surf. Proc. Land., 34(7), 969-980, 2009a.

Diodato, N. and Bellocchi, G.: Environmental implications of erosive rainfall across the Mediterranean, in: Environmental impact assessments, edited by: Halley, G. T. and Fridian, Y. T., NOVA Publishers, New York, NY, USA, 75-101, 2009b.

Diodato, N. and Fagnano, M.: A simple geospatial model climatebased for designing erosive rainfall pattern, in: The Environmental Pollution and its relation to Climate Change, edited by: El Nemr, A., in press, Springer, Nova Science Publishers, USA, 2009.

D'Odorico, P., Yoo, J., and Over, T. M.: An assessment of ENSOinduced patterns of rainfall erosivity in the Southwestern United States, J. Climate, 14, 4230-4242, 2001.

Ducci, D., Giugni, M., and Zampoli, M.: Evaluation of soil erosion process of the Tusciano river basin. In Proceeding: Soil and hillslope management using analysis and Runoff-erosion models: a critical evaluation of current technique, COST 634, Florence (Italy), 7-9 May 2007.

Easterling, D. R., Evans, J. L., Ya Groisman, P., Karl, T. R., Kunkel, K. E., and Ambenje, P.: Observed variability and trends in extreme climate events: a brief review, B. Am. Meteorol. Soc., 81, 417-425, 2000.

Esposito, E., Porfido, S., Violant, C., and Alaia, F.: Disaster induced by historical floods in a selected coastal area (Southern Italy), in: PHEFRA - Paleofloods, Historical Data \& Climatic Variability: Application in Flood Risk Assessmen, edited by: Thorndycraft, V. R., Benito, G., Barriendos, M., and Lalsat, M. C., Barcellona, 143-148, 2003.

Fagnano, M., Mori, M., Carone, F., and Postiglione, L.: Sistemi colturali per l'Appennino meridionale: Nota II. Deflussi ed erosione, Rivista di Agronomia, 34, 55-64, 2000 (in Italian).

Favis-Mortlock, D. T., Boardman, J., and MacMillan, V. J.: The limits of erosion modeling: why we should proceed with care, in: Landscape Erosion and Evolution Modeling edited by: Harmon, R. S. and Doe III, W. W., Kluwer Academic/Plenum Publishing, New York, 477-516, 2001.

Foster, G. R., Meyer, L. D., and Onstad, C. A.: A runoff erosivity factor and variable slope length exponents for soil loss estimates, T. ASAE, 20, 683-687, 1977.

Foster, G. C., Chiverrell, R. C., Harvey, A. M., Dearing, J. A., and Dunsford, H.: Catchment hydro-geomorphological responses to environmental change in the Southern Uplands of Scotland, The Holocene 18, 935-950, 2008.

Garcia-Oliva, F., Maass, J. M., and Galicia, L.: Rainstorm analysis and rainfall erosivity of a seasonal tropical region with a strong cyclonic influence on the Pacific Coast of Mexico, J. Appl. Meteorol., 34, 2491-2498, 1995.

Gobin, A., Jones, R., Kirkby, M., Campling, P., Govers, G., Kosmas, C., and Gentile, A. R.: Indicators for pan-European assessment and monitoring of soil erosion by water, Environ. Sci. Policy, 7, 25-38, 2004.

Gomez, B., Phillips, J. D., Migilligan, F. J., and James, L. A.: Floodplain sedimentation and sensitivity: summer 1993 flood, Upper Mississippi river valley, Earth Surf. Proc. Land., 22, 923 936, 1997.

Hollinger, S. E., Angel, J. R., and Palecki, M. A.: Spatial distribution, variation and trends in storm precipitation characteristics associated with soil erosion in the United States, Champaign, IL: United States Department of Agriculture and Atmospheric Environment Section (Illinois State Water Survey), 2002.

Hooke, D. D. and Mant, J. M.: Geomorphological impacts of a flood event of ephemeral cannels in SE Spain, Geomorphology, 34, 163-180, 2000.

Katz, R. W. and Brown, B. G.: Extreme events in a changing climate: Variability is more important than average, Climatic Change, 21, 289-302, 1992.

Lal, R.: Soil degradation by erosion, Land Degrad. Dev., 12, 520 539, 2001.

Larson, W. E., Lindstrom, M. J., Schumacher, and T. E.: The role of severe storm in soil erosion: a problem needing consideration, J. Soil Water Conserv., 52, 90-95, 1997.

Lim, K. J., Engel, B. A., Tang, Z., Choi, J., Kim, K., Muthukrishnan, S., and Tripathy, D.: Web GIS-based Hydrograph Analysis Tool, WHAT, J. Am. Water Resour. As., 41(6), 1407-1416, 2005.

Lu, H., Moran, C. J., Prosser, I. P., Raupach, R. M., Olley, J., and Petheram, C.: Sheet an rill erosion sediment delivery to streams: a basin wide estimation at hillslope to Medium catchment scale, Report E to Project D10012, CSIRO Technical Report 15/03, 56 pp., 2003.

Martínez-Casasnovas, J. A., Ramos, M. C., and Ribes-Dasi, M.: Soil erosion caused by extreme rainfall events: mapping and quantification in agricultural plots from very detailed digital ele- 
vation models, Geoderma, 105, 125-140, 2002.

Michael, A. J., Schmidt, W., Deutschlander, E. T., and Malitz, G.: Impact of expected increase in precipitation intensities on soil loss results of comparative model simulations, Catena, 61, 155164, 2005.

Morgan, R. P. C.: Soil erosion and conservation, 3rd edn., Blackwell Publishing Science Ltd., 304 pp., 2005.

Mul, M. L., Savenije, H. H. G., and Uhlenbrook, S.: Spatial rainfall variability and runoff response during an extreme event in a semiarid catchment in the South Pare Mountains, Tanzania, Hydrol. Earth Syst. Sci. Discuss., 5, 2657-2685, 2008, http://www.hydrol-earth-syst-sci-discuss.net/5/2657/2008/.

Nearing, M. A., Jetten, V., Baffaut, C., Cerdan, O., Couturier, A., Hernandez, M., Le Bissonnais, Y., Nichols, M. H., Nunes, J. P., Renschler, C. S., Souchére, V., and van Oost K.: Modeling response of soil erosion and runoff to changes in precipitation and cover, Catena, 61, 131-154, 2005.

Newson, M. and Lewin, J.: Climatic change, river flow extremes and fluvial erosion - scenarios for England and Wale, Prog. Phys. Geog., 15, 1-17, 1991.

Nash, J. E. and Sutcliffe, J. V.: River flow forecasting through conceptual models. Part I - a discussion of principles, J. Hydrol., 27, 282-290, 1970.

Onori, O., De Bonis, P., and Grauso, S.: Soil erosion prediction at the basin scale using the revised universal soil loss equation (RUSLE) in a catchment of Sicily (southern Italy), Environ. Geol., 50, 1129-1140, 2006.

Peterson, T. C., Taylor, M. A., Demeritte, R., Duncombe, D. L., Burton, S., Thompson, F., Porter, A., Mercedes, M., Villegasm E., Fils, R. S., Tank, A. K., Martis, A., Warner, R., Joyette, A., Mills, W., Alexander L., and Gleason, B.: Recent changes in climate extremes in the Caribbean region, J. Geophys. Res., 107(D21), 4601, doi:10.1029/2002JD002251, 2002.

Phillips, D. L., White, D., and Johnson, B.: Implications of climate change scenarios for soil erosion potential in the USA, Land Degrad. Rehabil., 4, 61-72, 2006.

Poesen, J. W. A. and Hooke, J. M.: Erosion, flooding and channel management in Mediterranean environments of southern Europe - Part II, Prog. Phys. Geog., 21, 179-199, 1997a.

Poesen, J. W. A. and Hooke, J. M.: Erosion, flooding and channel management in Mediterranean environments of southern Europe - Part I, Prog. Phys. Geog., 21, 157-178, 1997b.

Poesen, J. W. A., van Wesemael, B., Govers, G., MartinezFernandez, J., Desmet, P., Vandaele, K., Quine, T., and Degraer, G.: Patterns of rock fragment cover generated by tillage erosion, Geomorphology, 18(3-4), 183-197, 1997.

Quilbé, R., Rousseau, A. N., Moquet, J.-S., Savary, S., Ricard, S., and Garbouj, M. S.: Hydrological responses of a watershed to historical land use evolution and future land use scenarios under climate change conditions, Hydrol. Earth Syst. Sci., 12, 101-110, 2008, http://www.hydrol-earth-syst-sci.net/12/101/2008/.
Renard, K. G., Foster, G. R., Weesies, G. A., McCool, D. K., and Yoder, D. C.: Predicting soil erosion by water: a guide to conservation planning with the revised Universal Soil Loss Equation (RUSLE), Washington DC: Agricultural Handbook, United States Department of Agriculture, 1997.

Rickson, R. J.: Management of sediment production and prevention in River catcments: a matter of scale?, in: Soil Erosion and Sediment Redistribution in River Catchments, edited by: Owens, P. N. and Collins, A. J., CABI Publishing, UK, 228-238, 2006.

Rumsby, B. T.: Valley-floor and floodplain processes, in: Geomorphological processes and landscape change: Britain in the last 1000 years, edited by: Higgitt, D. L. and Lee, E. M., Blackwell Publisher, London, 90-115, 2001.

Saç, M. M., Uğur, A., Yener, G., and Özden, B.: Estimates of soil erosion using cesium-137 tracer models, Enviro. Monit. Assess., 136, 461-467, 2007.

SIMN: Annali del Servizio Idrografico \& Mareografico Nazionale, Roma, Istituto Poligrafico dello Stato Italiano, Parts I and II, 1950-2000.

Thornes, J. B.: The intercation of erosional and vegetational dynamics in land degradation: spatial outcomes, in: Vegetation and erosion, edited by: Thornes, J. B., J. Wiley \& Sons, 45-55, 1990.

Torri, D., Borselli, L., Guzzetti, F., Calzolari, M. C., Bazzoffi, P., Ungaro, F., Bartolini, D., and Salvador Sanchis, M. P.: Italy, in: Soil erosion in Europe, edited by: Boardman, J. and Poesen, J., John Wiley \& Sons, Ltd, 245-261, 2006.

Toy, T. J., Foster, G. R., and Renard, K. G.: Soil Erosion: Processes, Prediction, Measurement, and Control, John Wiley \& Sons, Inc., New York, 2002.

Tropeano, D.: Soil erosion problem in north-western Italy: a short overview, in: Soil Erosion Abridged Proceedings of the Workshop on Soil erosion and Conservation, an Assessment of the Problems and the State of the Art in EEC Countries, Florence, 19-21 October 1982, ECC, EUR 8427 Luxembourg, 36-41, 1983.

Van der Knijff, J. M., Jones, R. J. A., and Montanarella, L.: Soil erosion risk assessment in Italy, European Soil Bureau, JRC Report EUR 19022EN, 52 pp., 2000.

Vandewiele, G. L., Xu, C. Y., and Lar-Win, N.: Methodology and comparative study of monthly water balance models in Belgium, China and Burma, J. Hydrol., 134, 315-347, 1992.

Van Rompaey, A. J. J., Bazzoffi, P., Jones, R. J. A., Montanarella, L., and Govers, G.: Validation of soil risk assessment in Italy, European Soil Bureau, Research Report No. 12, EUR 20676 EN, 25 pp., 2003.

Yang, D., Kanae, S., Oki, T., Koike, T., and Musiake, K.: Global potential soil erosion with reference to land use and climate changes, Hydrol. Process., 17, 2913-2928, 2003.

Zachar, D.: Soil Erosion: Developments in Soil Science 10, Elsevier, 547 pp., 1982. 